\title{
Perpaduan Penggunaan WhatsApp Grup dan Google Class Room Pada Pembelajaran Bahasa Indonesia Di Masa Pandemi Covid-19
}

\author{
Yayu Mindartin \\ Guru SMPN 1 Taliwang \\ Email: yayumindartin12@gmail.com
}

\begin{abstract}
Abstrak: Penelitian ini bertujuan untuk meningkatkan hasil belajar siswa kelas IX SMPN 1 Taliwang di masa pandemi covid-19 pada mata pelajaran Bahasa Indonesia dengan memadukan penggunaan media pembelajaran WatshApp Grup dan Google Class Room. Penelitian tindakan kelas (PTK) ini di laksanakan di SMPN 1 Taliwang KSB pada kelas IX semester genap tahun pelajaran 2020/2021 dengan jumlah siswa 26 orang yang terdiri dari 6 siswa laki-laki dan 20 siswa perempuan. Penelitian ini dilaksanakan dalam 2 siklus dengan metode pembelajaran daring dalam kurun waktu 24 kali pertemuan termasuk tes harian, ujian tengah semester (UTS) dan Ujian Akhir Semester (UAS). Analisis data penelitian tindakan ini hanya dibatasi pada penyajian data tes harian yang dilakukan sebanyak 4 kali, UTS dan UAS. Hasil analisis data penelitian ini disajikan dalam bentuk tabel distribusi frekuensi dan diagram batang yang menunjukkan peningkatan hasil belajar siswa. Hasil Penelitian PTK ini dapat disimpulkan bahwa perpaduan penggunaan WatshApp Grup dan Google Class Room tidak hanya mampu meningkatkan hasil belajar siswa dalam pembelajaran daring. Namun disisi lain, penelitian ini mampu memberikan dampak pada pola pikir dan perubahan keperibadian guru dalam membuat perencanaan pembelajaran yang sistematis dan terukur berdasarkan hasil refleksi diri.
\end{abstract}

Kata Kunci: WatshApp, Google Class Room, Pembelajaran Bahasa Indonesia, Pandemi covid-19.

\section{PENDAHULUAN}

Tren Penggunakan berbagai media sosial di tengah wabah pandemic covid-19 menjadi semakain meningkat dan sangat fundamental khususnya di dunia Pendidikan (Maulana, 2021; Naserly, 2020; Nuryaningsih, 2021; Pustikayasa, 2019). Guru dan Siswa di tuntut untuk mampu menggunakan berbagai media sosial secara cermat dan terorganisir dalam proses pembelajaran. Agar mampu mencapai tujuan akhir pembelajaran yang direncanakan dalam proses pembejaran daring. Dua diantara media sosial yang paling banyak digunakan masa pandemi di bidang pendidikan adalah aplikasi WhatsApp Mobile/web(Hutami \& Nugraheni, 2020; Saragih \& Ansi, 2020) dan Google Class Room (Daniati et al., 2020; Santosa et al., 2020; Umairah \& Zulfah, 2020).

Aplikasi WhatsApp menjadi salah satu media sosial yang sangat populer dan paling aktif digunakan saat ini. Hal ini di karena kemudahan dalam penggunaannya dibandingkan media sosial lainnya (Nugroho et al., 2021). Melihat dari berbagai fitur yang ditawarkan oleh WhatsApp, grup WhatsApp menjadi fitur yang unik sebagai media untuk berkomunikasi dan bertukar berbagai file antara peserta dalam satu grup (Iskandar, 2020). WhatsApp merupakan salah satu aplikasi yang saat ini sudah banyak digunakan sebagai alat komunikasi termasuk di lingkungan dunia pendidikan dalam hal ini adalah guru maupun siswa (Saragih \& Ansi, 2020). WhatsApp merupakan aplikasi berbasis mobile phone dan web yang terintegrasi dengan berbagai aplikasi yang digunakan untuk berkomunikasi dengan pengguna lainnya, mulai dari pendidikan, bisnis, entertaiment banyak dikembangkan pada aplikasi ini. Aplikasi yang terus dikembangkan sekarang diharapkan fungsi dari aplikasi jejaring sosial seperti WhatsApp tidak hanya untuk chatting (obralan teks) dan broadcast pesan berantai saja, melainkan lebih ke kolaborasi aplikasi (collaboration applications) dan berbagi informasi (information sharing) lebih ditonjolkan sehingga tujuan dari e-learning benar-benar bisa dimanfaatkan (Prajana, 2017).

Dalam upaya mendukung kelangsungan proses pendidikan dan pembelajaran, grup WhatsApp dapat gunakan sebagai media pembelajaran, sehingga pembelajaran dapat terlaksana tanpa dibatasi ruang dan waktu (Iskandar, 2020; Rosdiana et al., 2020; Saragih \& Ansi, 2020). Dengan menggunakan grup WhatsApp, guru diharapkan tidak hanya melaksanakan pembelajaran berdasarkan kurikulum semata, tetapi juga dapat memberi dorongan untuk membangkitkan, merangsang dan meningkatkan motivasi belajar siswa, sehingga tujuan suatu pembelajaran dapat tercapai dengan baik. Adanya wabah virus covid- 
19 di Indonesia yang menyebabkan segala aktivitas harus di lakukan dari rumah. Sehingga dalam dunia pendidikan semua guru harus mampu membuat sedemikian hingga media pembelajaran yang dapat di operasikan secara efektif oleh siswa dari rumah (Hutami \& Nugraheni, 2020).

Sedangkan google classroom adalah salah satu akses gratis yang memudahkan guru dalam proses e-learning hanya login dengan menggunakan akun gmail. Lebih jauh, platform ini menawarkan banyak sekali keuntungan bagi penggunanya. Selain itu, platform ini dikenal sebagai alat yang mudah digunakan oleh pengguna smartphone atau laptop, serta mampu menciptakan peluang yang sama bagi semua siswa dan mendorong siswa untuk belajar lebih banyak tentang literasi internet (Hapsari \& Pamungkas, 2019).

Hasil penelitian menunjukkan bahwa aplikasi google classroom merupakan media pembelajaran yang sangat fleksibel tempat maupun waktu (Hapsari \& Pamungkas, 2019). Penggunaan aplikasi google classroom juga efektif dalam penyampaian materi maupun pengumpulan tugas karena tidaklah menggunakan alat tulis. Setiap guru dapat dengan mudah mengupload power point, video maupun soal soal dengan menggunakan google classroom (Salamah, 2020). Penelitian terhadap penggunakan google classroom baik dari tingkat SD hingga perguruan tinggi telah banyak di lakukan belakangan ini sebelum dunia dilanda oleh wabah covid-19 (Budiarti, 2019; Hapsari \& Pamungkas, 2019; Suhada et al., 2020). google classroom ini terbukti dapat meningkatkan kedisiplinan dalam pengumpulan tugas (Rosdiana et al., 2020). Selain itu, penggunaan Google Classroom terbukti dapat meningkatkan motivasi belajar dan hasil belajar siswa dengan adanya pengawasan orang tua dalam mengerjakan tugas (Budiarti, 2019; Daniati et al., 2020). Aplikasi google classroom juga merupakan aplikasi terbaik yang bisa di gunakan untuk pembelajaran karena pembelajaran yang di sajikan seperti pembelajaran yang dilakukan di kelas ofline, hanya saja dalam google classroom pembelajaran kelas online tidak bertatap muka secara langsung (Salamah, 2020).
Keberadaan kedua media sosial tersebut diatas dengan berbagai keunggulan dan manfaat tentu akan sangat membantu dan memudahkan guru dalam menyelesaikan tugas dan tanggung jawabnya dalam proses pembelajaran daring. Walaupun demikian, banyak guru yang merasakan bahwa pembelajaran daring dengan berbagai media social tersebut mengakibatkan hasil belajar dan motivasi belajar siswa menurun jika dibandingkan dengan pembelajaran langsung (tatap muka). Hal ini disebabkan guru dan siswa belum memahami betul cara penggunaan media daring yang efektif dan efesien dalam proses pembelajaran. Selain itu, hasil penelitian yang dilakukan oleh Asmuni (2020) menunjukkan bahwa pelaksanaan pembelajaran daring di masa pandemi covid-19 memiliki beragam problematika yang dialami guru, peserta didik, dan orangtua. Permasalahan dari guru berupa lemahnya penguasaan IT dan terbatasnya akses pengawasan peserta didik, dari peserta didik berupa kekurangaktifan mengikuti pembelajaran, keterbatasan fasilitas pendukung dan akses jaringan internet, sementara dari orangtua berupa keterbatasan waktu dalam mendampingi anaknya di saat pembelajaran daring.

Ditengah dunia dilanda pandemi covid19, Guru-guru yang biasanya mengajar di dalam kelas menjadi kebingungan dalam melaksanakan proses pembelajaran. Salah satu cara yang dilakukan guru adalah dengan memberikan tugas kepada siswanya melalui via whatssap grup saja. Namun usaha tersebut kurang memotivasi siswa dan justru dirasakan mengakibatkan hasil belajar menurun (Umairah \& Zulfah, 2020). Temuan lain dari hasil penelitian yang dilakukan oleh Santosa et al (2020) menyatakan bahwa penyempurnaan penerapan google classroom dalam pembelajaran adalah perlu adanya aplikasi pendukung yang dapat memfasilitasi guru dan siswa dapat bertatap muka langsung via jaringan (web). Oleh karena itu, perlu dilakukan penelitian untuk mengkolaborasikan kedua media pembelajaran daring tersebut. Sehingga, tujuan dari penelitian ini adalah memadukan penggunaan aplikasi watsApp dengan google classroom dalam upaya meningkatkan hasil belajar siswa kelas IX SMPN 1 Taliwang di masa 
pandemi covid-19 pada mata pelajaran bahasa indonesia.

\section{METODE}

Penelitian tindakan kelas (PTK) ini di laksanakan di SMPN 1 Taliwang KSB pada kelas IX semester genap tahun pelajaran 2020/2021 dengan jumlah siswa 26 orang yang terdiri dari 6 siswa laki-laki dan 20 siswa perempuan. Penelitian ini dilaksanakan mulai bulan Januari sampai dengan bulan Juni 2021. Penelitian tindakan kelas ini dilakukan untuk meningkatkan hasil belajar siswa kelas IX SMPN 1 Taliwang di masa pandemi covid-19 pada mata pelajaran Bahasa Indonesia dengan memadukan penggunaan media pembelajaran WatshApp Grup dan Google Class Room.

Penelitian ini dilaksanakan dalam 2 siklus dengan metode pembelajaran daring dalam kurun waktu 24 kali pertemuan termasuk tes harian, ujian tengah semester (UTS) dan Ujian Akhir Semester (UAS). Adapun rincian kegiatan pada siklus 1 terdiri dari kegiatan pembelajaran awal semester genap dan diakhiri dengan UTS, sedangkan siklus 2 dilaksanakan mulai kegiatan pembelajaran setelah UTS dan diakhiri dengan UAS. Tiap siklus terdiri dari empat tahap, yaitu tahap perencanaan, tahap pelaksanaan tindakan, tahap observasi dan evaluasi serta tahap refleksi. Berikut ini adalah gambaran keempat langkah dalam penelitian tindakan kelas yang dikemukakan oleh Arikunto (2010).

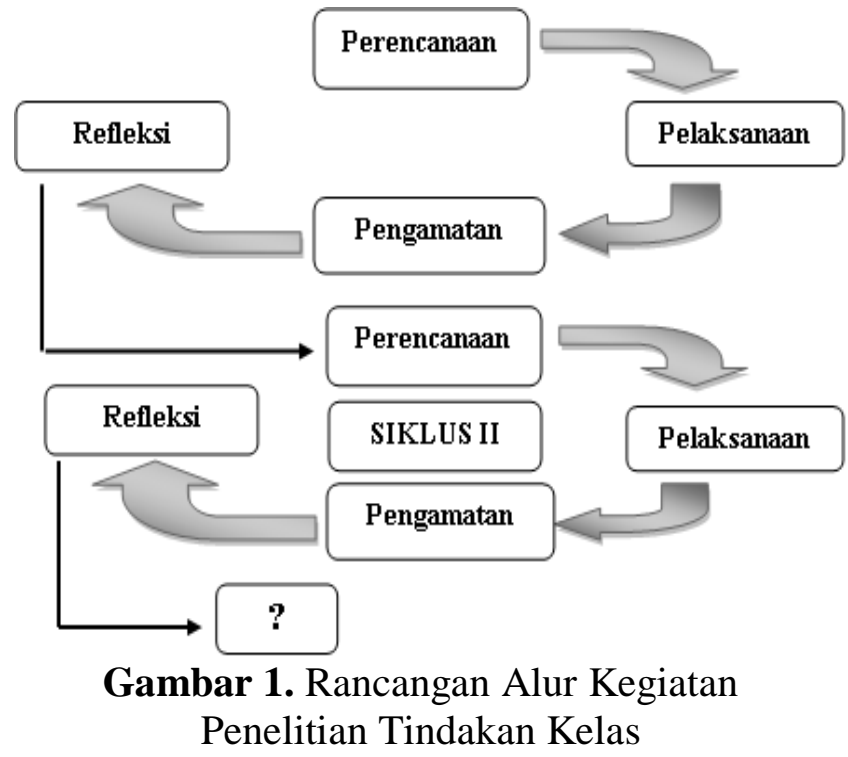

Dalam artikel ini, analisis data penelitian tindakan ini hanya dibatasi pada penyajian data tes harian yang dilakukan sebanyak 4 kali, UTS dan UAS. Hasil analisis data penelitian ini disajikan dalam bentuk tabel distribusi frekuensi dan diagram untuk mengetahui dampak pembelajaran daring dengan memanfaatkan aplikasi watshApp dan GCR di masa pandemi covid-19.

Adapun kegiatan pembelajaran di WatshApp Grup dikhususkan untuk memberikan informasi tentang kegiatan pembelajaran yang akan dilakukan siswa, wadah diskusi siswa dan guru di luar jam pembelajaran, dan wadah guru untuk memberi dorongan untuk membangkitkan, merangsang serta meningkatkan motivasi siswa untuk tetap semangat belajar dari rumah. Sedangkan kegiatan pembelajaran di GCR digunakan guru untuk mengupload file buku atau LKS, video, membuat presensi maupun soal soal tes dan siswa juga dengan mudah mengakses fasilitas pembelajaran yang sudah di upload guru serta wadah mengirimkan semua tugas bagi siswa.

\section{HASIL DAN PEMBAHASAN}

Penelitian tindakan ini telah dilaksanakan dalam 2 siklus dengan 6 pokok bahasan materi antara lain 1)

Adapun hasil penelitian dijelaskan dalam tulisan ini di fokuskan pada perbandingan hasil tes tiap siklus termasuk tes harian pada masingmasing siklus tindakan yang diuraikan sebagai berikut. Pada siklus 1 dilaksanakan 2 kali tes harian. Berikut disajikan perbandingan hasil tes harian siklus 1 seperti yang disajikan dalam tabel 1 dan 2 dibawah ini:

Tabel 1: Distribusi frekuensi hasil tes harian 1 siklus 1

\begin{tabular}{|c|c|}
\hline Nilai Tes Harian 1 & Frekuensi \\
\hline $65-70$ & 3 \\
\hline $71-76$ & 6 \\
\hline $77-82$ & 6 \\
\hline $83-88$ & 6 \\
\hline $89-94$ & 2 \\
\hline $95-100$ & 3 \\
\hline Total & 26 \\
\hline
\end{tabular}


Tabel 2: Distribusi frekuensi hasil tes harian 2 siklus 1

\begin{tabular}{|c|c|}
\hline Nilai Tes Harian 2 & Frekuensi \\
\hline $88-89$ & 6 \\
\hline $90-91$ & 11 \\
\hline $92-93$ & 0 \\
\hline $94-95$ & 0 \\
\hline $96-97$ & 0 \\
\hline $98-100$ & 9 \\
\hline Total & 26 \\
\hline
\end{tabular}

Pada tabel 1 menunjukkan bahwa terdapat 9 siswa yang tidak tuntas dengan memperoleh nilai dibawah KKM 76 pada mata pelajaran Bahasa Indonesia. Terdapat 3 siswa yang memperoleh nilai terendah 65 dan 6 orang memperoleh nilai 75 . Sedangkan nilai maksimum dari tes harian ini sebesar 95 yang berhasil diaraih oleh 3 orang siswa. Selanjutnya pada tabel 2 menunjukkan bahwa semua siswa telah memenuhi ketuntasan belajar dengan memperoleh nilai diatas KKM yang di tetapkan. Nilai terendah yang diperoleh oleh siswa pada tes harian 2 adalah 88 dan nilai maksimum 100 . Untuk lebih memperjelas perbandingan hasil tes harian pada siklus 1 disajikan pada diagram batang dibawah ini.

\section{Diagram batang Nilai}

\section{Tes Harian 1}

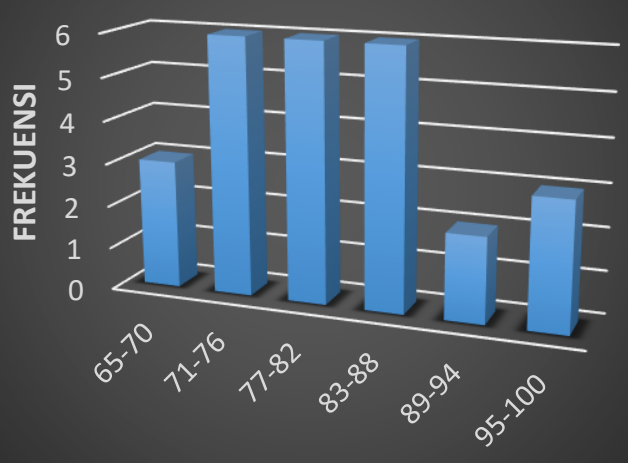

NILAI TES

Gambar 1. Diagram Batang Hasil Tes Harian 1 Siklus 1

\section{Diagram batang Nilai} Tes Harian 2

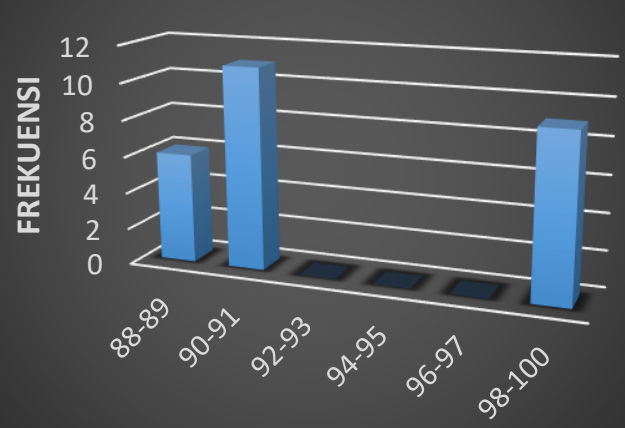

NILAI TES

Gambar 2. Diagram Batang Hasil Tes Harian 2 Siklus 1

Pada diagram batang gambar 1 diatas nampak bahwa sebaran nilai tes harian 1 siswa berada pada interval 71-88 dengan jumlah siswa 18 orang, sisanya 3 siswa memperoleh nilai di bawah 71 dan 5 siswa memperoleh nilai diatas 88. Sedangakan pada diagram batang gambar 2 nampak bahwa 11 siswa memperoleh nilai terbanyak pada interval 90-91 dan sisa 6 siswa memperoleh nilai di bawah 90 serta 9 siswa memperoleh nilai sempurna tertinggi yaitu 100 . Adapun nilai rata-rata tes harian 1 dan 2 secara berturut-turut adalah 80,76 dan 93. Hal ini menunjukkan bahwa hasil belajar siswa mengalami peningkatan 12,24 poin.

Sejanjutnya tes terakhir yang dilakukan pada siklus 1 berupa tes Ujian Tengah Semester (UAS) yang di sajikan pada tabel 3 berikut ini.

Tabel 3: Distribusi frekuensi hasil Ujian Tengah Semester siklus 1

\begin{tabular}{|c|c|}
\hline Nilai UTS & Frekuensi \\
\hline $83-85$ & 0 \\
\hline $86-88$ & 4 \\
\hline $89-91$ & 6 \\
\hline $92-94$ & 6 \\
\hline $95-97$ & 3 \\
\hline $98-100$ & 7 \\
\hline Total & 26 \\
\hline
\end{tabular}

Pada tabel 3 menunjukkan bahwa semua siswa sudah tuntas secara klasikal dengan nilai terendah 86 dan nilai tertinggi 100. Siswa yang 
memperoleh nilai sempurna 100 ada 7 orang. Hasil tes akhir siklus 1 ini memberikan dampak pada peningkatan hasil belajar siswa yang dipengaruhi oleh kesadaran guru dalam melakukan refleksi diri pada tiap akhir pembelajaran. Guru terus berusaha mencermati kesesuain aktivitas siswa dalam pembelajaran daring dengan tujuan pembelajaran yang ingin di capai. Hasil belajar siswa pada siklus 1 diperjelas pada diagram batang berikut ini

\section{DIAGRAM BATANG TES SIKLUS 1}

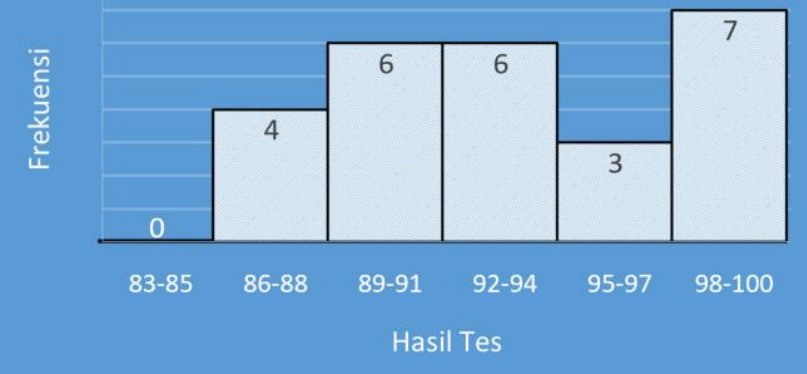

Gambar 3. Diagram Batang Hasil Tes UJianTengah Semester pada Siklus 1

Rata-rata hasil belajar siswa setelah melakukan pembelajaran daring yang dilakukan kurang lebih 10 kali pertemuan sebesar 93.30. Hasil ini menunjukan peningkatan hasil belajar siswa jika dibandingkan dengan hasil ter harian yang telah dilakukan sebanyak 2 kali.

Walaupun hasil tes pada siklus 1 telah memenuhi standar ketuntasan klasikal dan penelitian dikatakan berhasil. Namun untuk mengetahui kekonsistenan media pembelajaran daring yang dilakukan dalam penelitian ini. Maka penelitian tindakan ini dianggap perlu untuk dilanjutkan pada siklus 2 dengan materi pembelajaran Bahasa Indonesia yang di pelajari adalah materi setelah UTS. Adapaun hasil tes pada siklus 2 disajikan sebagai berikut.

Tabel 4: Distribusi frekuensi hasil tes harian 1 siklus 2

\begin{tabular}{|c|c|}
\hline Nilai Tes Harian 1 & Frekuensi \\
\hline $70-74$ & 4 \\
\hline $75-79$ & 0 \\
\hline $80-84$ & 4 \\
\hline $85-89$ & 0 \\
\hline $90-94$ & 9 \\
\hline $95-100$ & 9 \\
\hline Total & 26 \\
\hline
\end{tabular}

Pada tabel 4 menunjukkan bahwa terdapat 4 siswa memperoleh nilai dibawah KKM 76 pada tes 1 siklus 2. Namun tren siswa yang memperoleh nilai sempurna 100 menjadi 8 orang jika dibandingkan dengan hasil tes akhir siklus 1 dan rata-rata nilai siswa sebesar 88,73. Sedangkan tes harian kedua pada siklus 2 mengalami peningkatan pada tren siswa yang memperoleh nilai 100 menjadi 9 orang seperti yang disajikan pada tabel 5 dibawah ini.

Tabel 5: Distribusi frekuensi hasil tes harian 2 siklus 2

\begin{tabular}{|c|c|}
\hline Nilai Tes Harian 2 & Frekuensi \\
\hline $77-80$ & 3 \\
\hline $81-84$ & 0 \\
\hline $85-88$ & 1 \\
\hline $89-92$ & 5 \\
\hline $93-96$ & 6 \\
\hline $97-100$ & 11 \\
\hline Total & 26 \\
\hline
\end{tabular}

Pada tabel 5 menunjukkan bahwa semua siswa sudah tuntas secara klasikal dengan nilai terendah 80 dan nilai tertinggi 100 dengan nilai rata-rata sebesar 94.07 yang tinggi dibandingkan dengan tes siklus 1 maupun tes harian siklus 1 pada siklus 2. Adapun diagram batang hasil akhir siklus 2 dari hasil Ujian Akhir Semester (UAS) ditunjukkan pada gambar 4 berikut ini.

Diagram Batang hasil tes siklus 2

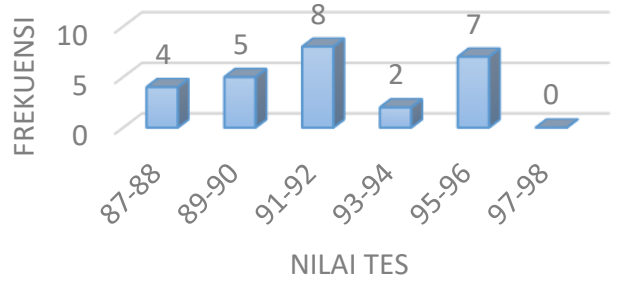

Gambar 4. Diagram Batang Hasil Tes UJian Akhir Semester (UAS) pada Siklus 1

Berdasarkan diagram batang diatas, hasil tes akhir siklus 2 mengalami penurunan tren nilai 100 hingga $100 \%$. Namun mengalami meningkatan pada nilai minimum siswa di bandingkan tes-tes sebelumnya dan juga rata-rata sebaran nilai siswa berkisar pada interval 90-96. Hal ini dapat dimaknai bahwa kemampun siswa 
terus mengalami peningkatan dan masih dapat di pertahankan bagi siswa yang selalu mendapat nilai 100 .

Hasil penenelitian tindakan ini memberikan tambahan referensi bagi para guru bahwa dengan memamdukan media pembelajaran daring antara wathasapp grup dan google classroom ataupun dengan media lain akan mampu memberikan dampak pada peningkatan hasil belajar siswa. Handphone yang didalam tersedia berbagai apliksi dapat dimanfaatkan sebagai media pembelajaran online secara efektif. Sebagaimana penelitian yang di dilakuan oleh Sauhenda et al. (2019) menjelasakan bahwa penggunaan HP berpengaruh secara positif dan signifikan terhadap prestasi belajar bahasa Indonesia siswa SMP. Namun tentu harus dibarengi dengan kemauan dan kecermatan guru bidang studi untuk merancang pembelajaran nya yang efektif.

Dengan menerapkan pembelajaran berbasis teknologi informasi daring dimasa pandemic covid-19 memungkinkan siswa memiliki keleluasaan dalam belajar tanpa dibatasi ruang dan waktu dalam belajar (Rosdiana et al., 2020). Praktik keberhasilan pemanfaatan aplikasi watsApp dan google classroom dalam penelitian ini didukung oleh hasil penelitian penelitian sebelumnya (Asmuni, 2020; Naserly, 2020; Nuryaningsih, 2021).

\section{KESIMPULAN}

Penelitian PTK ini tidak hanya mampu meningkatkan hasil belajar siswa dalam pembelajaran daring dengan memadukan wathasapp grup dan google classroom. Namun disisi lain, penelitian ini mampu memberikan dampak pada pola pikir dan perubahan keperibadian guru dalam membuat perencanaan pembelajaran yang sistematis dan terukur dari hasil refleksi diri.

\section{SARAN}

Saran bagi guru dan penelitian lainnya, agar praktik penelitian serupa lebih di tekankan pada aktifitas siswa yang terbimbing dalam kegiatan pembelajaran daring. Jangan terlalu banyak diberikan tugas mandiri setelah pembelajaran daring. Namun lebih banyak tugas pratik dalam proses pembelajaran daring dengan cara tanya jawab dan diskusi terbuka. Selain itu, perlu disikapi bahwa tidak semua siswa akan betah mengikuti proses pembelajaran daring, sehingga perlu ada selingan kegiatan permainan yang mendukung pembelajaran.

\section{DAFTAR PUSTAKA}

Asmuni. (2020). Problematika pembelajaran daring di masa pandemi covid-19 dan solusi pemecahannya. Jurnal Paedagogy: Jurnal Penelitian Dan Pengembangan Pendidikan, 7(4), 281-288.

Budiarti, W. N. (2019). Meningkatkan motivasi belajar Bahasa Indonesia SD menggunakan google classroom. DWIJA CENDEKIA: Jurnal Riset Pedagogik 3, 3(2), 257-263.

Daniati, Ismanto, B., \& Luhsasi, D. I. (2020). Upaya peningkatan motivasi dan hasil belajar mahasiswa dengan penerapan model pembelajaran e-learning berbasis google classroom pada masa pandemi covid-19. Jurnal Kependidikan: Jurnal Hasil Penelitian Dan Kajian Kepustakaan Di Bidang Pendidikan, Pengajaran Dan Pembelajaran, 6(3), 601-608.

Hapsari, S. A., \& Pamungkas, H. (2019). Pemanfaatan google classroom sebagai media pembelajaran online di Universitas Dian Nuswantoro. WACANA, 18(2), 225233.

Hutami, M. S., \& Nugraheni, A. S. (2020). Metode pembelajaran melalui whatsapp group sebagai antisipasi penyebaran covid-19 pada AUD di TK ABA Kleco Kotagede. PAUDIA, 9(1), 126-130.

Iskandar, R. (2020). Penggunaan grup whatsapp sebagai media pembelajaran derhadap peserta Didik DTA At-Tawakal Kota Bandung. Community Education Journal, 3(2), 97-101.

Maulana, H. A. (2021). Persepsi mahasiswa terhadap pembelajaran daring di Pendidikan Tinggi Vokasi: studi perbandingan antara penggunaan google classroom dan zoom. EDUKATIF: JURNAL ILMU PENDIDIKAN, 3(1), 188-195.

Naserly, M. K. (2020). Implementasi zoom, 
google classroom, dan whatsapp group dalam mendukung pembelajaran daring (online) pada mata kuliah bahasa inggris lanjut (Studi Kasus Pada 2 Kelas Semester 2, Jurusan Administrasi Bisnis, Fakultas Ekonomi dan Bisnis, Universitas Bina Sa. EDUTECH CONSULTANT BANDUNG Jurnal AKSARA PUBLIC, 4(2), 155-165.

Nugroho, I., Sumekar, W., \& Prayoga, K. (2021). Hubungan frekuensi penggunaan whatsapp terhadap keberhasilan pemasaran kopi di Gapoktan Gunung Kelir Kecamatan Jambu Kabupaten Semarang. AGROLAND: JURNAL ILMU-ILMU PERTANIAN, 28(1), 17-31.

Nuryaningsih, W. D. (2021). Penerapan model discovery learning berkolaborasi google classroom dan whatsapp group untuk meningkatkan kompetensi siswa dalam menulis teks eksplanasi. Jurnal Paedagogy: Jurnal Penelitian Dan Pengembangan Pendidikan, 8(2), 159168.

Prajana, A. (2017). Pemanfaatan aplikasi whatsapp dalam media pembelajaran di UIN Ar-Raniry Banda Aceh. Cyberspace: Jurnal Pendidikan Teknologi Informasi, 1(2), 122-133.

Pustikayasa, I. M. (2019). Grup whatsApp sebagai media pembelajaran (whatsApp group as learning media). Jurnal Ilmiah Pendidikan, Agama Dan Kebudayaan Hindu, 10(2), 53-62. https://doi.org/10.36417/widyagenitri.v1 $0 \mathrm{i} 2.281$

Rosdiana, L. A., Sukawati, S., \& Firmansyah, D. (2020). Meningkatkan kedisiplinan melalui google classroom dalam mata kuliah Bahasa Indonesia. Semantik, 9(1), 35-40.

https://doi.org/10.22460/semantik.vXiX. XXX

Salamah, W. (2020). Deskripsi penggunaan aplikasi google classroom dalam proses pembelajaran. Jurnal Penelitian Dan Pengembangan Pendidikan, 4(3), 533538.

Santosa, F. H., Negara, H. R. P., \& Bahri, S. (2020). Efektivitas pembelajaran google classroom terhadap kemampuan penalaran matematis siswa. Jurnal Pemikiran Dan Penelitian Pendidikan Matematika (JP3M), 3(1), 62-70. https://doi.org/10.36765/jp3m.v3i1.254

Saragih, E. M., \& Ansi, R. Y. (2020). Efektivitas penggunaan whatsapp group selama pandemi covid-19 bagi pelaku pendidik. Prosiding Seminar Nasional Multidisiplin Ilmu Universitas Asahan Ke-4 Tahun 2020 Tema: "Sinergi Hasil Penelitian Dalam Menghasilkan Inovasi Di Era Revolusi 4.0", September, 207212.

Sauhenda, A. F., Kidahane, A. K., \& Werang, B. R. (2019). Pengaruh penggunaan handphone terhadap prestasi belajar bahasa indonesia siswa. JURNAL MAGISTRA, 6(1), 34-44.

Suhada, I., Kurniati, T., Pramadi, A., \& Listiawati, M. (2020). Pembelajaran Daring Berbasis Google Classroom Mahasiswa Pendidikan Biologi Pada Masa Wabah Covid -19. Digital Library UIN Sunan Gunung Djati.

Umairah, P., \& Zulfah. (2020). Peningkatan motivasi belajar menggunakan " google classroom " ditengah pandemi covid-19 pada peserta didik kelas XI IPS 4 SMAN 1 Bangkinang Kota. Journal On Education, 02(03), 275-285. 